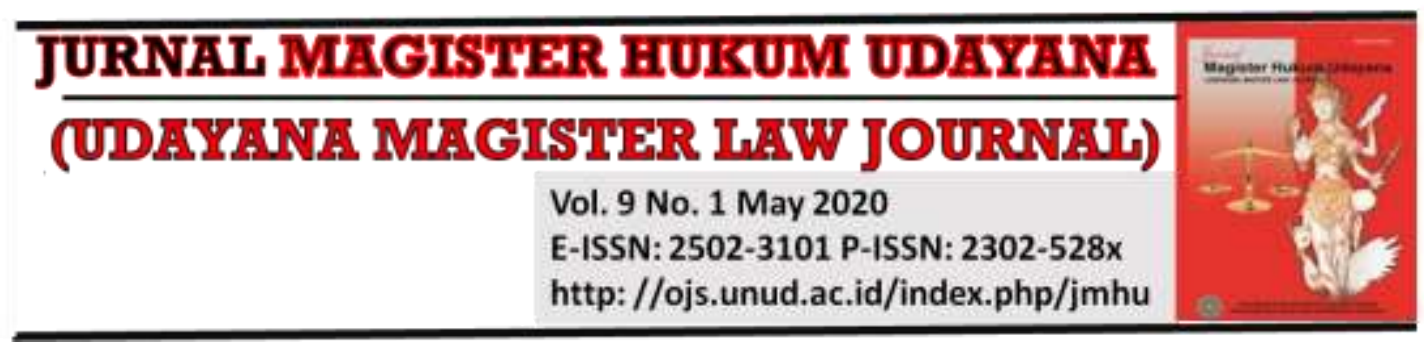

\title{
The Principle of Iknemook for Mediator in Medical Malpractice Dispute Settlement Through Mediation
}

\author{
I Made Wirya Darma1, I Gusti Agung Ayu Mas Triwulandari², \\ I Gede Agus Kurniawan ${ }^{3}$
}

\begin{abstract}
${ }^{1}$ Faculty of Law and Sosial Science Undiknas University, E-mail: dedukdd81@gmail.com ${ }^{2}$ Faculty of Law and Sosial Science Undiknas University, E-mail: agungmas84@yahoo.com ${ }^{3}$ Faculty of Law and Sosial Science Undiknas University, E-mail: aguskurniawan2015@gmail.com
\end{abstract}

\begin{tabular}{l}
\hline Info Article \\
\hline Received: $16^{\text {th }}$ April 2020 \\
Accepted: $30^{\text {th }}$ May 2020 \\
Published: $31^{\text {st }}$ May 2020 \\
Keywords: \\
Iknemook Principles; Medical \\
Malpractice Dispute; Medical \\
Malpractice Mediation \\
Corresponding Author: \\
I Made Wirya Darma, Email: \\
dedukdd81@gmail.com \\
DOI: \\
10.24843/JMHU.2020.v09.i01. \\
p03
\end{tabular}

\begin{abstract}
The agreement is made to undertake a treatment for an illness, which resulted in the conclusion of a therapeutic contract under Laws as regulated under Article 1233 of the Civil Code of Indonesia (Kitab Undang-Undang Hukum Perdata). Every legal relationship will result in rights and obligations. Medical malpractice is usually caused by an unfulfillment of a patient's basic rights because of the lack of communication or information, which are the basic rights of a patient. The dispute settlement through court system is unsatisfactory for either patient or doctor. Therefore, a dispute settlement that is considered ideal is through non-litigation process, which is mediation, to achieve win-win solution. Procedures for mediators to mediate such malpractice dispute are in accordance to seven principles, which are also regarded as the seven bbaasic philosophies of mediation for medical dispute, which are known as the principle of Iknemook. The contents of the Iknemook principle for mediator in medical malpractice dispute settlement through mediation are the problems in this research. This research aims to assess and study the seven principles of Iknemook for mediator in medical malpractice dispute settlement through mediation. This research is categorised as a library research with a specification of descriptive research, which is presented to explain Iknemook principles for mediator in medical malpractice dispute settlement through mediation. This research finds that the principles comprised of the principles of good faith of both parties, trust, neutrality, exclusivity of a mediator (med-power), open-mind, autonomy, and confidentiality.
\end{abstract}

\section{Introduction}

A discussion about medical malpractice is not new in Indonesia. Some cases have occurred, but the resolution is not optimal given the laws and regulations in Indonesia so far have not yet regulated about medical malpractice (it does not mean there are no cases of malpractice). Thus, legal actions for medical malpractice are qualified as an act of negligence (culpa). Negligence, according to Article 1366 of the Indonesian Civil Code, is a lack of attentiveness of a professional to work in accordance with the 
standards expected of his profession, which causes harm to others. Negligence can occur due to inadvertency (culpa), carelessness, indifference. The consequences that arise are not the purpose of the action. The important thing is to realise that a small or trivial error or negligence in the medical field can have serious or fatal consequences.

Malpractice means running a job that is poor quality, not lege artist, not right. Malpractice is not only found in the medical field, but also other professions such as banking, lawyers, public accountants, and journalists. Thus, medical malpractice can be interpreted as the negligence or failure of a doctor or medical staff to use the level of skills and knowledge commonly used in treating patients or injured people according to size in the same environment. ${ }^{1}$ Based on understanding in the Black's Law Dictionary, medical malpractice is "medical malpractice is a doctor's failure to exercise the degree of care and skill that a pyysicion or surgeon of the same medica specially would use under similar circumstance". ${ }^{2}$ So malpractice can occur due to failure of actions, certain bad behavior and others as well as unfamiliarity or competence of an action below the average which causes loss.

Medical malpractice can occur due to an action that fails (not intentions) as in certain misconduct, negligence, neglected actions or actions below the standards of a profession or an inadequacy/incompetence in the same scope, that result in losses. ${ }^{3}$ Regarding medical actions taken by doctors, always results in two possibilities, namely success and failure. The failure of a doctor in carrying out medical actions is caused by two things, the first is caused by overmacht (force majeure), the second is caused by the doctor taking medical actions that are not in accordance with the standards of the medical profession. ${ }^{4}$ This can cause conflicts between doctors and patients, which can lead to disputes. But many factors can trigger disputes other than those mentioned earlier, including changes in the pattern of relations between doctors and patients. Initially the relationship between doctors and patients is paternalistic, which dictates that patient participation is only to obey the healer. Patients are considered not to know and do not need to know about the causes of the disease because the disease is a manifestation of God's curse. Basically, the settlement of a medical malpractice case through litigation is intended to hold the doctor accountable so that the doctor can be subjected to criminal, civil or administrative sanctions, but in this study the author only focuses on resolving medical malpractice disputes through mediation.

One of the policies offered as a model for resolving medical malpractice in Indonesia in the future is the medical dispute resolution model through the Medical Dispute Resolution Institution. This institution is specifically formed to resolve medical disputes that arise. The trial procedures and mechanisms are used quickly, precisely and do not require expensive costs. This Medical Dispute Settlement Institution is an effort to solve specific medical dispute problems and is an answer to resolve medical disputes that has been felt unsatisfactory by either the public or patients when they

${ }^{1}$ Fitriono, R. A., Setyanto, B., \& Ginting, R. (2016). Penegakan Hukum Malpraktik Melalui Pendekatan Mediasi Penal. Yustisia Jurnal Hukum, 5(1), 148-161

${ }^{2}$ Henry Campbell Black, ed Bryan. (2009). Black'sLaw Dictuonary, Ninth Edition, Printed in the USA, p. 1044

3 Soetrisno, S., (2010), Malapraktik Medik \& Mediasi, Cetakan Pertama, Telaga Ilmu Indonesia, Tangerang, h.4

4 Anny Isfandyarie, (2005), Malpraktek Dan Resiko Medik Dalam Kajian Hukum Pidana, Prestasi Pustaka, Jakarta, h. 24-25 
have to litigate before a court because doctors are difficult to punish and always conspire with Indonesian Doctors Association (IDI) to protect fellow doctors. Likewise for doctors, the existence of the justice system so far is a scary thing because besides having to go through a mechanism/procedure that is protracted, there is a risk of providing compensation, which sometimes doubles the amount of salary received, it can also damage the reputation that has been fostered so far. ${ }^{5}$

In general, mediation can be divided into two parts, the first mediation in court institutions (in court) as stipulated in the technical implementation PERMA 12016 on Mediation Procedure of the Court. The second part of the mediation outside the court (out of court), it is moved from the provisions of Article 29 of Act 36 of 2009 and Section 6 of Act 30 of 1999. The process of mediation in medical malpractice dispute resolution set in PERMA 1 2016, there are two phases, phase pra-mediation and mediation stage. ${ }^{6}$

The Medical Dispute Settlement Institution is one of the institutions formed by Laws, and its members consist of law graduates, medical law academics, practitioners and representatives of the medical profession (Indonesian Doctors Association and Medical Council). This institution must be independent like an ad hoc judiciary and have several advantages including the existence that can be directly controlled/supervised, a regular funding, a decision that is final and can be directly executed. Even so, what needs to be examined is who can become a member and what/how is the position of members who are appointed and dismissed, because this concerns the issue of the existence and continuation of the institution itself. This is to avoid the impression that if the appointed member is an internal member of a medical organisation it is feared that he will continue to protect his colleagues and not fight for the interests of the patients. Likewise, in appointing an advisor, it is necessary to pay attention to the requirements that must be met, because the position has an important role in the success of resolving disputes. The foresight and experience of an advisor is needed to explain the position or situation of each party in the dispute.

The establishment of an independent institution is expected to reduce the function, authority and power of the Medical Council in regulating and overseeing the medical profession, for example in terms of imposing sanctions, overseeing expired practices, or overseeing excess practice quotas and so on, relating to the implementation of medical practice. This is important considering that in the future, the Medical Council is expected to focus more on taking care of the medical education, both for general and specialist. This institution has a trial procedure using one form of Alternative Dispute Resolution (ADR), namely the Mini Trial Institution. Mini trial is a new form of ADR and is very popular in the American business community. This form is considered the most effective and efficient option in resolving disputes. If the parties agree to seek resolution through a mini trial, then the process of resolving the mini trial model consists of 5 (five) quick and simple steps, as follows: (1) Approval of the mini trial or known as the agreement to use mini trial, meaning the parties agree to resolve the dispute via a mini trial institution; (2) Case preparation is limited to a period of 1 to 2 months. The purpose of the preparation of the case provides the opportunity for the

${ }^{5}$ Rizka Andri Fitriano, Budi Setyanto, Rehnalemken Ginting, (2016), Penegakan Hukum Malpraktik Melalui Pendekatan Mediasi Penal, Yustisia Edisi 9, 4 Januari -April 2016, h.91-92

6 Sukmawan, Y. A., \& Khisni, A. (2019). Legal Protection Of Health Worker In The Medical Malpractice Lawsuit In Banjarmasin. Jurnal Daulat Hukum, 2(2), 263-270. 
parties to collect various documents deemed important to be submitted in connection with the dispute in question; (3) Information hearing. At this stage, the mini trial process begins to be commenced in a closed meeting attended by the parties. The position of the advisor is not as a judge but acts as a neutral third party guiding the delivery of information; (4) The advisor provides an opinion; at this stage the parties must be present alone and not accompanied by a lawyer. The contents of the opinion explain the strengths, vices and weaknesses of each party, and how it would be if the case was brought before the court by litigation. Even though the opinion of the advisor is not binding, both on the parties or court judges; (5) Discuss settlement. The parties hold a meeting and without the presence of the advisor, because since he expressed his opinion, his role and function ended automatically. Whether or not the dispute resolution agreement is reached is entirely up to the parties concerned. ${ }^{7}$

\section{Research Method}

The research method that will be used in this research is a normative legal research method. The writing of this research is analytical descriptive, that is to describe data or a picture as carefully as possible regarding the object of the problem. The technique of collecting legal materials, following the research stage above, is by conducting a literature study, which consists of a study on national legal instruments, laws and regulations that have a direct linkage to medical malpractice issues, including the Civil Code of Indonesia, the Law Number 36 of 2009 concerning Health, and Law Number 30 of 1999 concerning Arbitration and Alternative Dispute Resolution.

\section{Result and Discussion}

\subsection{Mediation as the Primary Option in Medical Malpractice Dispute Resolution}

Humans are social creatures (zoon politicon) who live in groups and have interdependence between one another, the condition of dependence is the law of nature that is formed by the existence of mutual interests in the scope of the community. Disputes, disagreements, and arguments are the efforts to maintain the establishment and recognition in the process of achieving an interest.

In the event of malpractice, there is an imbalance in position between the patient and the doctor who is handling it. When the patient in question is concerned, he does not know about the operational standard of services provided, the patient believes that the doctor has the expertise for it. In the case of malpractice, the patient becomes a victim of careless actions and there is no competence from the doctor who treats the patient. As a result of errors or negligence can result in patients not recovering even more severe pain, may be disabled or even died. There some patients suffer losses and result in these patients being disabled due to the wrong doctor handling them ${ }^{8}$. From the case will arise losses for both parties, both patients and doctors themselves whose reputation will be bad in the community (reputation risk).

\footnotetext{
7 Bambang Tri Bawono, (2011), Kebijakan Hukum Pidana Dalam Upaya Penanggulangan Malpraktik Profesi Dokter, , Jurnal Hukum, 25(1), 453-473

8 Ernika, K., \& Sudibya, K. (2018). Analisis Pertanggungjawaban Perdata Seorang Dokter Dalam Kasus Malpraktek. Kertha Semaya : Journal Ilmu Hukum, 6(12), h. 1
} 
The more complex human interests in a civilization lead to the higher potential for disputes that occur between groups in certain social populations ${ }^{9}$. Dispute resolution procedures that are often used by many people are through mediation, because the increasing use of mediation is built upon people's understanding of what mediation is, which becomes clearer that there is an importance for the involvement of a mediator who has skills. In medical malpractice disputes, it relates to disputes that occur between doctors and patients that are usually caused by a lack of information from doctors. ${ }^{10}$ Information about everything related to medical actions carried out by doctors is the right of patients protected by the Law. Dispute resolution which is considered the most ideal for the parties is a settlement that involves the parties directly, allowing open dialogue, thus a joint decision is most likely to be reached. According to Article 29 of Law Number 36 of 2009 concerning Health, it has been regulated that alleged negligence by health workers in carrying out the profession must be resolved first through mediation.

\subsection{Iknemook Principles for Mediators in the Settlement of Medical Malpractice Disputes through Mediation}

Moral is a problem that arises when doctors neglect repeatedly and without any remorse. This is to be able to avoid it has made regulations that prevent negligence resulting in harm to patients. Law Number 36 Year 2009 regarding health, stipulates that in the case of health workers suspected of negligence in carrying out their profession, negligence must be resolved first by mediation. "In the relationship between the patient and the doctor is a civil law relationship, both of them if they choose the non-litigation path will take the mediation path as the way to resolve their dispute.

The increasingly complex forms of medical disputes require a model of resolution that can decipher problems more broadly, comprehensively and flexibly by involving the disputing parties in the decision making process; (b) Able to reduce the number of medical disputes resolved through litigation / court channels, to reduce the accumulation of cases in this court channel. Through the Medical Dispute Settlement Institution it will be able to foster trust and ultimately will be the patient's choice to resolve his dispute with a doctor / dentist / health care facility; (c) Able to deal with patient / family complaints in obtaining protection, even though the resolution of this dispute may not be satisfying. However, the existence of this model is expected to be able to provide solutions for both patients and health professionals in solving medical problems, without having to involve many unauthorized people. ${ }^{11}$

Mediation is the main effort in solving medical dispute cases. With the mediation process, it is expected that the patient doctor relationship will be maintained and reach a win-win solution peace agreement. By mediating the settlement of Medical Malpractice, it is hoped that the patient doctor's relationship will always be

${ }^{9}$ Umam, Khotibul., (2010), Penyelesaian Sengketa di Luar Pengadilan, Pustaka Yustisia, Yogyakarta, h. 9

10 Sumartono, Gatot.,(2006,) Arbitrase dan Mediasi di Indonesia, Gramedia Pustaka, Jakarta, h. 133

${ }^{11}$ Fitriono, R. A., Setyanto, B., \& Ginting, R. (2016). Penegakan Hukum Malpraktik Melalui Pendekatan Mediasi Penal. Yustisia Jurnal Hukum, 5(1), 148-161. 
maintained. ${ }^{12}$

In some regions in Indonesia, the usual effort to tackle malpractice can be done in 2 ways, namely, penal and non-penal. First, the attempt to punish, the handling of malpractice is carried out in a repressive manner (law enforcement), which begins with a notification via broadcast of alleged malpractice. While the Medical Ethics Honorary Council sought mediation after receiving complaints and received clarification in handling malpractice. ${ }^{13}$

There are 7 (seven) principles that must be understood by the mediator in medical dispute resolution through mediation to achieve the goal of a win-win solution. ${ }^{14}$ These seven principles are also called the seven basic philosophies of mediating medical dispu)tes. The seven principles are known as the Iknemook Principles, which consist of: ${ }^{15}$

a. The Principle of Good Faith

Both parties to the dispute must have common interest from the hearts and minds to resolve the dispute through mediation as they consciously make a choice of their desires and wishes, voluntarily and there is no coercion and pressure from other parties or third parties or advocate. The principle of good faith is built on the basis that the parties need each other, doctors have no intention of harming their patients and have the same view that the motivation for resolving disputes is merely to reconcile.

b. The Principle of Trust

This principle is intended to build commitment between patients, doctors and mediators who must trust each other. This principle cannot stand alone, the principle is presented by the mediator together with other principles that show the mediator's neutrality in leading the mediation process.

c. The Principle of Neutrality

In mediation, the implementation of this principle is important to be stated explicitly when the mediator first communicates the rules of mediation or at the time of introduction, the mediator needs to realise that the role of a mediator is only to facilitate the process, and the rests are depending to the parties to the dispute. The mediator is only authorised to lead and control the process of mediation. In mediation, a mediator does not act like a judge or jury who decides the wrong or right of one party or supports the opinion of one of them, or enforces his opinion and resolution to both parties, but the mediator also has the role of controlling the mediation process if the situation heats up and a non-conducive

${ }^{12}$ Wikrama, A. N. J., \& Santosa, A. G. D. H. (2015) Penyelesaian Malpraktik Antara Health Care Provider Dengan Health Care Reciever Pada Pelayanan Medik Melalui Mekanisme Mediasi Di Rumah Sakit Puri Kawan Sejahtera Denpasar. Kertha Semaya: Journal Ilmu Hukum.3(3), 1

${ }^{13}$ Ginting, V. P. B. (2017). Penanggulangan Malpraktek Yang Dilakukan Oleh Tenaga Kesehatan (Studi di Wilayah Bandar Lampung). POENALE: Jurnal Bagian Hukum Pidana, 5(2), h. 10

${ }^{14}$ Lihat juga, Kimberlee. K. Kovach. (2000). Mediation Principle and Practice, Thomson WestUSA, p. 1

15 Riyadi Machli, (2018), Teori Iknemook Dalam Mediasi Malpraktik Medik, Kencana, Jakarta,. 127132 
atmosphere occurs, then the mediator can stop or delay or suspend the mediation process and reschedule at a specified time together.

d. The Principle of Exclusive Mediator

The principle of exclusive mediator is also called the heart of mediation settlement (med-power), this principle is a principle that distinguishes specifically compared to the mediation process in civil cases in general, this principle provides confirmation that the mediator who completes the case of medical malpractice must have knowledge in in the field of health sciences and also having knowledge in the field of legal science in general, more specifically in medical law. It is on this principle that the ability of a mediator in controlling the mediation process is demanded to be able to influence (correcting misconceptions) the parties, that he or she is aware of the case being disputed.

e. The Principle of Open Mind

Generally, a patient who sues a doctor is often a patient who does not know the process, nature and object of the legal relationship between patients and doctors, and vice versa, they do not understand the benefits of mediation. The implementation of this principle requires the mediator to expand the horizon into the legal aspects of medical malpractice and explain some of the benefits of mediation and also to explain the length of time and the amount of money spent if a dispute is pursued via litigation and a mediator is demanded to approach the parties from the perspectives of humanities and their religions.

f. The Principle of Autonomy

This principle is based on the belief that patients and doctors have inherent human rights that must not be intervened by any party, including their legal counsels, the mediator gives absolute freedom and is directed to the resolution of the problems they experience, minimising some differences between the parties and most importantly the mediator guides the parties to follow their consciences and the mediator builds awareness of the nature of the creation of identity as human beings who need each other and love peace.

g. The Principle of Confidentiality

This principle assures the parties to the dispute that what happens in the meeting held by the mediator and the parties to the dispute may not be known to the public or the press by each party. Likewise, the mediator assures that the parties' secrets will be protected and if necessary destroyed.

\section{Conclusion}

A mediator must master the 7 (seven) principles in the resolution of medical disputes through mediation so that the goal of a win-win solution can be achieved. These seven principles are also called the seven basic philosophies of medical dispute mediation and are known as the Iknemook Principles, which consist of the principle of good faith, the principle of trust, the principle of neutrality, the principle of exclusive mediator (med-power), the principle of being open mind, the principle of autonomy, and the principle of confidentiality. To avoid medical malpractice disputes, an understanding of the parties is needed, in this case the doctor must understand the rights and 
responsibilities of his profession, and the patient must also understand the protection of the rights and obligations that must be implemented.

\section{References \\ $\underline{\text { Books }}$}

Gatot, S. (2006). Undang-Undang Tentang Arbitrase dan Mediasi di Indonesia. Jakarta: Gramedia Pustaka

Garner, B. A. (2009). Blacks Law Dictionary, ninthedition. New York, NY: Thomas Reuters Westlaw.

Isfandyarie, A. (2005). Malpraktek dan resiko medik dalam kajian hukum pidana. Jakarta: Prestasi Pustaka Publisher.

Khotibul, Umam. (2010). Penyelesaian Sengketa di Luar Pengadilan. Yogyakarta: Pustaka Yustisia

Kimberlee. K. Kovach. (2000). Mediation Principle and Practice. West USA: Thomson

Machli, R. (2018). Teori Iknemook Dalam Mediasi Malapraktik Medik. Jakarta, Prenadamedia Group.

Soetrisno, S. (2010). Malapraktik Medik \& Mediasi. Cetakan Pertama. Tanggerang: Telaga Ilmu Indonesia

Witanto, D. Y. (2011). Hukum acara mediasi: dalam perkara perdata di lingkungan peradilan umum dan peradilan agama: menurut PERMA no. 1 tahun 2008 tentang prosedur mediasi di pengadilan. Bandung: Alfabeta.

\section{Journal}

Bambang Tri Bawono. (2011). Kebijakan Hukum Pidana Dalam Upaya Penanggulangan Malpraktik Profesi Dokter, Jurnal Hukum, 25(1), 453-473

Bawono, B. T. (2020). Kebijakan Hukum Pidana dalam Upaya Penanggulangan Malpraktik Profesi Medis. Jurnal Hukum, 25(1), 453-473.

Ernika, K., \& Sudibya, K. (2018). Analisis Pertanggungjawaban Perdata Seorang Dokter Dalam Kasus Malpraktek. Kertha Semaya : Journal Ilmu Hukum, 6(12)

Fitriono, R. A., Setyanto, B., \& Ginting, R. (2016). Penegakan Hukum Malpraktik Melalui Pendekatan Mediasi Penal. Yustisia Jurnal Hukum,5(1), 148-161. https://doi.org/10.20961/yustisia.v5i1.8724

Ginting, V. P. B. (2017). Penanggulangan Malpraktek Yang Dilakukan Oleh Tenaga Kesehatan (Studi di Wilayah Bandar Lampung). POENALE: Jurnal Bagian Hukum Pidana, 5(2)

Sukmawan, Y. A., \& Khisni, A. (2019). Legal Protection Of Health Worker In The Medical Malpractice Lawsuit In Banjarmasin. Jurnal Daulat Hukum, 2(2), 263270. http://dx.doi.org/10.30659/jdh.2.2.\%25p

Wikrama, A. N. J., \& Santosa, A. G. D. H. (2015) Penyelesaian Malpraktik Antara Health Care Provider Dengan Health Care Reciever Pada Pelayanan Medik Melalui Mekanisme Mediasi Di Rumah Sakit Puri Kawan Sejahtera Denpasar. Kertha Semaya: Journal Ilmu Hukum.3(3)

\section{Laws and regulations}

Law Number 36 of 2009 concerning Health

Supreme Court Regulation No. 1 of 2016 concerning Mediation Procedures in the Court 